\title{
STATISTICAL EVALUATION OF PRE-SELECTION CRITERIA FOR INDUSTRIALIZED BUILDING SYSTEM (IBS)
}

\author{
Mohamed Nor Azhari AZMANa ${ }^{\mathrm{a}}$, Mohd Sanusi S. AHAMAD ${ }^{\mathrm{b}}$, Taksiah A. MAJID ${ }^{\mathrm{b}}$, \\ Ahmad Shukri YAHAYA ${ }^{\mathrm{b}}$, Mohd Hanizun HANAFI ${ }^{\mathrm{c}}$ \\ ${ }^{a}$ Faculty of Technical and Vocational Education, Universiti Pendidikan Sultan Idris (UPSI), \\ 35900 Tanjong Malim, Perak \\ ${ }^{b}$ School of Civil Engineering, Engineering Campus, Universiti Sains Malaysia (USM), \\ 14300 Nibong Tebal, Penang, Malaysia \\ c School of Housing, Building and Planning, Main Campus, Universiti Sains Malaysia (USM), \\ 11800 Penang, Malaysia
}

Received 14 Apr 2012; accepted 17 May 2012

\begin{abstract}
The Malaysian government has endorsed the use of an industrialized building system (IBS) in domestic projects. These have shifted the focus of the nation's construction industry towards mass production and modular products. A proper study on site selection criteria for new IBS precast manufacturing sites has now become essential. The preliminary study in this research determines the IBS precast manufacturing site selection criteria from literature reviews. Questionnaires pertaining to IBS acceptance and preference criteria were send to manufacturers, policymakers, academicians and contractors. The outcome analyses the respondents' view towards 15 site selection criteria. The result from the ANOVA statistical test indicates that most respondents agreed with the selected criteria except political and regulation criteria, urban requirement criteria, and personal criteria. However, there is a significant difference within the opinions of the contractors and manufacturers sector. Likewise, the mean ranking analysis of criteria shows significant difference in their preferences. The ideal rank of criteria preferred by the correspondents are costs, transportation and optimum distance, land sites, resources and utilization, infrastructures, economy markets, labour, inter-industry linkage, environmental risk, competition, personal, population, capacity, political and regulatory, and urban criteria.
\end{abstract}

Keywords: prefabrication, site selection, precast manufacturing, statistical analysis.

Reference to this paper should be made as follows: Azman, M. N. A.; Ahamad, M. S. S.; Majid, T. A.; Yahaya, A. S.; Hanafi, M. H. 2013. Statistical evaluation of pre-selection criteria for industrialized building system (IBS), Journal of Civil Engineering and Management 19(Supplement 1): S131-S140. http://dx.doi.org/10.3846/13923730.2013.801921

\section{Introduction}

In the first quarter of 2010, Malaysia's economy achieved a growth of $10.1 \%$. Manufacturing and construction were the two major sectors, which showed an increase growth of $16.9 \%$ and $8.7 \%$ respectively (MITI 2010). IBS manufacturing in the construction industry is one of the factors that have contributed to the economic growth in the manufacturing sector. The trend of the Malaysian construction industry has moved from the traditional method to IBS manufacturing and similarly, the productivity have moved from project based to product based. IBS is defined as, "An innovative process of building construction using concept of mass-production of industrialized systems, produced at the factory or onsite within controlled environments, it includes the logistic and assembly aspect of it, done in proper coordination with thorough planning and integration" (Kamar et al. 2011). Thus, Industrialised
Building System (IBS) is the term used to represent the prefabrication and construction industrialisation concept in Malaysia. The phenomenal transition of the construction industry to prefabricate manufacturing has also occurred in Australia, Hong Kong, Singapore and United Kingdom (Blismas, Wakefield 2009; Tam 2007; Tuan Seik 2001; Lovell, Smith 2010; Azman et al. 2010a). The implementation of prefabrication in the construction industry has enhanced productivity and improved quality as well as several benefits viz. shortened construction time, lower overall construction cost, improved quality, enhanced durability, better architectural appearance, enhanced occupational health and safety, material conservation, less construction site waste, less environmental emissions, and reduction of energy and water consumption (Chen et al. 2010).

Malaysia has adopted "off-site" construction since the 1960s, where the term used was industrialized build-

Corresponding author: Mohamed Nor Azhari Azman

E-mail:syurga7181@yahoo.com 
ing system (Azman et al. 2010b). The Construction Industry Development Board (CIDB), which forms a part of the governmental agency, conducted a series of surveys in 2003, 2005, and 2008 to authenticate the increasing awareness on the IBS concept in construction (Majid et al. 2011). CIDB Malaysia as a statutory body under the Ministry of Works has been promoting the industrialization of the construction sector through the IBS Roadmap 2003-2010. The IBS Roadmap was approved by the Cabinet in October 2003 with the objective of providing guidelines for the establishment of an industrialized construction sector as well as the creation of an open construction system by 2010 . The development of this roadmap was based on the "5M strategy" (machinery, manpower, material, measurement, and method), and it will be implemented gradually in governmental projects (CIDB 2003).

Based on the latest CIDB news (2010) the number of IBS products has increased rapidly due to the introduction of the authorization policy, where $70 \%$ of IBS components must be utilized in governmental projects worth RM10 million and above (Treasury 2008). While approaching 2014, it will be compulsory for private projects to use $50 \%$ of IBS components in their construction. Azman et al. (2011) highlighted that in 2009 there were 15 IBS precast manufacturing plants in operation where in 2011 the number has gradually increased by almost twofold.

The above shows that contractors and manufacturers have played their role in expanding the construction industry with the widespread use of IBS according to the stipulated government regulations. In addition, the development of IBS factories depends on the physical location, technology, system used, quality of mass production, and product demand. The Construction Industry Development Board (CIDB) through the IBS Centre conducts research on IBS in collaboration with researchers from universities and active players of IBS. The research findings will form the basis for governmental policies.

In line with the determination of multiple site selection criteria for new IBS precast manufacturing, multicriteria decision-making (MCDM) is vital. It has been an important part of management sciences over the century (Farahani et al. 2010). Site selection criteria are dynamic, and these will expand as they vary with time and global development.

The scope of this research did not involve MCDM analysis. Only the term multiple criteria are used to define the sets of criteria for IBS site selection purposes. The initial stage of the work statistically identifies the significance of the multiple criteria proposed for IBS manufacturing site. Moreover, there are no universal techniques available for selecting a set of evaluation criteria but the set of evaluation criteria can be developed through an examination of the relevant literature, analysis study and opinions (Keeney, Raiffa 1976). The statistical method is preferred in evaluating the criteria and the questionnaire survey will balance the approach and provides a reasonable mechanism for selecting the set of criteria.

The number of IBS precast manufacturing has increase significantly as the result of both governmental and private projects requiring the usage of IBS products. This is a good opportunity for the new IBS player to be involved in the IBS precast manufacturing business. Therefore, an appropriate study is required to review and validate the multiple criteria through decision makers directly involved in IBS.

This paper identifies multiple criteria for IBS sites through literature review. The methodology evaluates these criteria by means of quantitative survey via questionnaire. The sampling part is critical in ensuring good selection of respondents in the data analysis. The statistical analysis applies rigorous statistical tests such as reliability data analysis, mean rating, ANOVA and Duncan Multiple Range Test (DMRT). The outcome of the paper highlights the ranking of multiple site selection criteria for IBS manufacturing.

\section{Literature review}

The theory and knowledge of location science were first pioneered by Weber (1909), who introduced four main criteria for site selection: distance, markets, resources, and labour. The introductory case study starts with the problem of locating a single warehouse to minimize the total travel between the warehouse and a set of distributed customers. The warehouse should also be positioned in the locality of raw materials as well as the vicinity of the market area. On the aspect of labour pool factor, it is acquired that manpower should be located near the warehouse in order to take advantages of low wage costs. For instance, there is a need for further analysis on the multi criteria decision making problem for the site selection of IBS precast manufacturing, which is a significant attribute of the warehouse case study. This demonstrates the key role of warehouses in developing countries that are rigorously applying the modern supply chain process.

In the context of the Malaysian industry, Singh (1976) enumerated 11 site selection criteria based on Weber's findings. Other significant case studies pertaining to site selection criteria are as follow: Sinuany-Stern et al. (1995), Lahdelma et al. (2002), Tzeng et al. (2002), Kahraman et al. (2003), Rachdawon, Apawootichai (2003), Aras et al. (2004), Norese (2006), Tabari et al. (2008), Chou et al. (2008), Chang et al. (2008), Tuzkaya et al. (2008), Chou, Chang (2008), Vahidnia et al. (2009), Shen, Yu (2009), Fernandez, Ruiz (2009), Lin, Juan (2009), Ekmekcioglu et al. (2010), and Sener et al. (2010). The site selection criteria for IBS manufacturing plants are based on the groundwork of mentioned literature, in addition to reference guided by the multiple criteria decision making (MCDM) application for single objective site selection. 
A total of 15 common site selection criteria were identified and listed in rank order (most commonly found in literature and considered as the most important) in Table 1. The rank order of criteria shows that transportation and optimum distance are the most common, followed by cost. Transportation and optimum distance collectively form a criterion that cannot be separated. They are interrelated and have variable time effects for future development and expansion. The second important criterion is cost, which can be categorized as fixed and variable. Fixed cost is the initial investment for land, building, and equipment. Meanwhile, variable cost pertains to transportation, logistics, production, services, maintenance, environment protection, safety, and workers. Transportation cost is always the highest, followed by installation cost (Farahani et al. 2010).

The environmental criteria began to surface in literature in the 1990s. At present, it has become the most essential among all site selection criteria as worldwide trend has moved toward sustainable development and green technology. Market economic criteria are focused on supply and demand issues of products among consumers, or provision of services for long-term expansion of construction projects. The ability to forecast the future market in the development of potential projects is important for both government and the private sector, as this allows them to measure the number of value projects to be released in the future.

In addition to market economy, infrastructure criteria such as roads, water supply, sewers, power grids, telecommunications, and so forth are the main target for future project development. These contribute the basic needs of physical and organizational structures of a development area. The higher service facilities of infrastructure will enhance the production of goods and services. For example, roads enable the transport of raw materials to a factory, and facilitate the distribution of finished products to markets.

The availability of resources is dependent on the market's economic demand and readiness of infrastructure to transport raw materials. In literature, the resource criteria are found to be important during the 1980s. In the 1990s, however, the criteria became less important due to the rapid development of infrastructures worldwide, particularly road facilities.

The population criterion refers to demographic data as well as collection of gross domestic product (GDP) per capita in a potential region for future development. Demographic criteria found in literature are specific for site selection of hospitals, restaurants, waste treatment, industrial estate, wind station, landfills, and eco-industrial and park resorts. They become essential for sociological discipline and statistical study of human populations.

Land site criteria are syndromes of human activities such as agriculture, forestry, and building construction that alter land surface processes, including biogeochemistry, hydrology, and biodiversity. Social scientists and land managers define land sites more broadly as land use. This includes the social and economic purposes and contexts for and within which lands are managed (or left unmanaged), such as subsistence versus commercial agriculture, rented versus owned, or private versus public land.

Although the political and regulatory criterion does not rank among the popular ones for site selection as indicated in Table 1, it remains to influence the initial stage of project approval as it requires time and affects the cost of miscellaneous projects. Even if the projects are completely built up, it continues to require quick execution approval for the handover of projects to clients.

From the economic point of view, labour is a main measurement of productivity per country. In the in late 1990s, labour was an important site selection criterion, but its importance diminished over time with the development of technology and increase in human resources. Thus, labour can be congregated from the local market or overseas. The development of human skill is easily obtainable. Meanwhile, most machines have become userfriendly, triggering a decrease in the number of skilled workers.

The urban criterion has been spawned by high population density, becoming essential for addressing site selection problems for restaurants, eco-industrial parks, and resort parks. Urban areas may include cities, towns, or conurbations that focus on high development areas. In fact, urbanized areas agglomerate and grow along with the core population/economic activity centre within a larger metropolitan area.

Parallel to the expansion of an urban area, competition may contribute to the site selection criteria, especially for restaurants, facility locations, and hotels. There will be a contest among individuals, groups, and nations for territory, a niche, or a location of resources. This arises whenever two or more parties strive for a goal that cannot be shared. Competition occurs naturally between living organisms that coexist in the same environment. Business is often associated with competition as most companies compete over the same group of customers.

Development productivity requires the capacity criteria for site selection. The production is focused on the market and the ability to produce mass production. Hence, there is a need for a certain level of capacity to sustain production, such as the size of land, resources, and maximum production. Thus, it refers to the relationship between actual output that "is" produced with the installed equipment and the potential output that "could" be produced with it, if capacity were fully utilized.

Inter-industry linkage is a less popular criterion, as indicated in Table 1. The purpose of inter-industry linkage is to have a networking industry that supports raw material production or services. Nowadays, the market industry has grown globally, indicating that industry linkage can be communicated by wireless technology and online services. This has caused inter-industry linkage to become a less important criterion. 
Table 1. Ranking of Site Selection Criteria (literature summary)

\begin{tabular}{|c|c|c|c|c|c|c|c|c|c|c|c|c|c|c|c|c|}
\hline Authors/ Criteria & 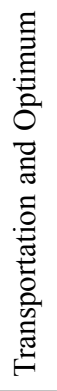 & 莕 & 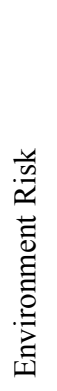 & 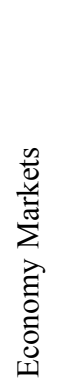 & 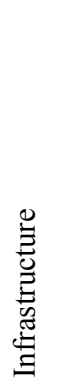 & 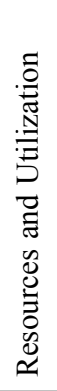 & 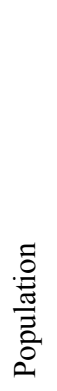 & 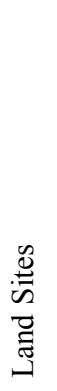 & 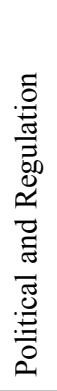 & 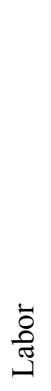 & 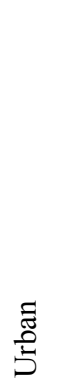 & 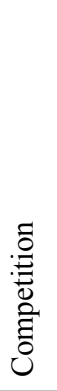 & 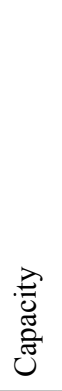 & 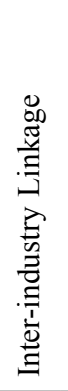 & 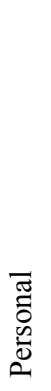 & Location \\
\hline Weber (1909) & $*$ & & & $*$ & & * & & & & $*$ & & & & & & Industry \\
\hline Singh (1976) & $*$ & $*$ & & $*$ & $*$ & $*$ & & * & $*$ & $*$ & $*$ & & & $*$ & $*$ & $\begin{array}{l}\text { Malaysian } \\
\text { Industry }\end{array}$ \\
\hline Sinuany-Stern et al. (1995) & $*$ & & & & $*$ & & $*$ & & & $*$ & & & & & & Hospital \\
\hline Lahdelma et al. (2002) & $*$ & $*$ & $*$ & & & * & $*$ & $*$ & & & & & & & & $\begin{array}{l}\text { Waste } \\
\text { Treatment }\end{array}$ \\
\hline Tzeng et al. (2002) & $*$ & $*$ & $*$ & & $*$ & & * & & & & $*$ & * & * & & & Restaurant \\
\hline Kahraman et al. (2003) & & & & $*$ & & & & & * & & & * & & & & $\begin{array}{l}\text { Facility } \\
\text { Location }\end{array}$ \\
\hline Rachdawong \& Apawootichai (2003) & & & $*$ & & $*$ & & * & & & & & & & & & $\begin{array}{l}\text { Industrial } \\
\text { Estate }\end{array}$ \\
\hline Aras et al. (2004) & * & $*$ & $*$ & & & $*$ & $*$ & & & & & & & & & Wind Station \\
\hline Norese (2006) & $*$ & & $*$ & $*$ & & & $*$ & $*$ & & & & & $*$ & & & $\begin{array}{l}\text { Waste } \\
\text { Treatment }\end{array}$ \\
\hline Tabari et al. (2008) & & $*$ & & $*$ & & $*$ & & $*$ & $*$ & & & & & & & Ware-house \\
\hline Chou et al. (2008) & $*$ & $*$ & & & & $*$ & & & $*$ & & & $*$ & & & & Hotel \\
\hline Chang et al. (2008) & * & & $*$ & & & & $*$ & $*$ & & & $*$ & & & & & Landfill \\
\hline Tuzkaya et al. (2008) & * & $*$ & $*$ & $*$ & & & & & & $*$ & & & $*$ & & & $\begin{array}{l}\text { Undesi-rable } \\
\text { Facility }\end{array}$ \\
\hline Chou \& Chang (2008) & $*$ & $*$ & & $*$ & $*$ & * & & & & & & & & & & $\begin{array}{l}\text { Supplier } \\
\text { Selection }\end{array}$ \\
\hline Vahidnia (2009) & & $*$ & $*$ & & & & $*$ & * & & & & & & & & Hospital \\
\hline Shen \& Yu (2009) & $*$ & & & $*$ & & & & & $*$ & & & & & & & $\begin{array}{l}\text { Facility } \\
\text { Location }\end{array}$ \\
\hline Fernández \& Ruiz (2009) & $*$ & $*$ & $*$ & $*$ & $*$ & $*$ & $*$ & & & & $*$ & & & & & $\begin{array}{l}\text { Eco-industrial } \\
\text { Park }\end{array}$ \\
\hline Lin \& Juan (2009) & & $*$ & & $*$ & $*$ & $*$ & $*$ & & $*$ & $*$ & $*$ & & & $*$ & & Resort Park \\
\hline Ekmekcioglu (2010) & $*$ & $*$ & $*$ & & $*$ & & & & & & & & & & & $\begin{array}{l}\text { Municipal } \\
\text { Solid Waste }\end{array}$ \\
\hline Sener et al. (2010) & $*$ & & $*$ & & $*$ & & & $*$ & & & & & & & & Landfill \\
\hline
\end{tabular}

Personal criterion, which is based on owner needs and interest in setting up the industry location, is the least popular criterion for site selection. An organization generally conducts a proper study to select the best location for its business based on the essential criteria of site selection. Typically, the criteria will be based on the economy, sociology, technology, and demographic data.

\section{Methodology}

The " 15 criterion" method as mentioned in the literature review is used for the survey. Feedbacks are obtained quantitatively where questionnaires based on the " 15 criterion" were designed using inputs from the reviewed summary as shown in Table 1. For the questionnaire, 29 questions in Table 2 were set out to help determine the site selection criteria for the new IBS precast manufacturing site. The methodology for the preliminary study is akin to that used by Adetunji et al. (2003) and Dulai- 
Table 2. List of 29 Questions for 15 Site Selection Criteria

\begin{tabular}{|c|c|c|}
\hline No & Criteria & Description \\
\hline 1 & $\begin{array}{l}\text { Transportation and } \\
\text { Optimum Distance }\end{array}$ & $\begin{array}{l}\text { 1. Maximum coverage and minimize the travel distance } \\
\text { 2. Access to roads for loading/unloading }\end{array}$ \\
\hline 2 & Environmental Risk & $\begin{array}{l}\text { 3. Nature habitat and human are protected } \\
\text { 4. Convenience place of handling construction waste } \\
\text { 5. Far from disaster area }\end{array}$ \\
\hline 3 & Costs & 6. Lowest operational costs \\
\hline 4 & Market Economy & $\begin{array}{l}\text { 7. Central to major markets } \\
\text { 8. Area of high purchasing power } \\
\text { 9. Low tax } \\
\text { 10. Recycle-reuse revenue }\end{array}$ \\
\hline 5 & Infrastructure & $\begin{array}{l}\text { 11. Social facilities for workers } \\
\text { 12. Good public transport } \\
\text { 13. Benefits from the industrial estate } \\
\text { 14. Benefits from the free-trade zones } \\
\text { 15. Availability of power and water } \\
\text { 16. Proximity to airport/ sea port/ railways }\end{array}$ \\
\hline 6 & $\begin{array}{l}\text { Resources and } \\
\text { Utilization }\end{array}$ & $\begin{array}{l}\text { 17. Close to raw materials \& cheap raw materials } \\
\text { 18. Ready supply of abundant quantities }\end{array}$ \\
\hline 7 & Land Sites & $\begin{array}{l}\text { 19. Relatively cheap land sites } \\
\text { 20. Near to development areas }\end{array}$ \\
\hline 8 & Population & $\begin{array}{l}\text { 21. Suitability to the nearest residential \& development area } \\
\text { 22. Quality manpower }\end{array}$ \\
\hline 9 & Political and Regulation & $\begin{array}{l}\text { 23. Proximity to the Ministry/Govt. offices for quick execution of plans and awareness of new } \\
\text { rules \& regulations }\end{array}$ \\
\hline 10 & Urban & 24. Within or near an urban centre of over 50,000 population size \\
\hline 11 & Capacity & 25. Site capacity, sewage capacity \\
\hline 12 & Labor & 26. Availability of labor \& low labor cost \\
\hline 13 & Competition & 27. Number of competitor, intensity of competition \\
\hline 14 & Personel & 28. Attractive environment $\&$ ideal location \\
\hline 15 & Inter-industry Linkage & 29. Forward industrial linkage with other firms in Malaysia \\
\hline
\end{tabular}

mi et al. (2004), which comprise of questionnaire design, questionnaire survey, and a statistical of the survey data. This research uses the 10-point Likert scale, where ordinal scales were used to transform the respondent's opinions into a scale to facilitate statistical analysis. A better illustration of the 10-point Likert scale can be obtained from Table 3. Flynn et al. (1990) indicated that interval measures may be added or subtracted at points where it is compatible with various statistics.

\section{Sampling selection}

A total of 110 respondents ranging from policymakers, academicians, manufacturers and contractors with 5-15 years of industrial experience were involved with the IBS survey. The IBS industry has been actively nurtured ever since the usage of IBS components in governmental projects have been made compulsory since 2008. The method of stratified random sampling was chosen, which comprises of policymakers (20), academicians (15) and manufacturers (25). On the other hand, the contractors were chosen from the top 50 companies that have been short listed by the Construction Industry Development Board (CIDB). The rational of using stratified random
Table 3. The Comparison Definition 10-Point Likert Scale

\begin{tabular}{cc}
\hline $\begin{array}{c}\text { Intensity of Importance } \\
\text { Likert Scale }\end{array}$ & Definition \\
\hline $0-2$ & Not Important \\
\hline $2-4$ & Less Important \\
\hline $4-6$ & Important \\
\hline $6-8$ & Very Important \\
\hline $8-10$ & Absolute Important \\
\hline
\end{tabular}

sampling is that it is able to represent each preference group proportionately (Balnaves, Caputi 2001). This is particularly important in cases where overview preferences might want to over-represent a particular stratum, especially if there are very low numbers.

To ensure better response, the survey forms were distributed by hand and follow-up were made via telephone. Subsequently, such efforts ensured better response as mentioned by Synodios (2003) and help to explain its objective while obtaining broader inputs from the respondents. Part of the questionnaire was also sent by email. Altogether, 50 surveys were successfully completed with a response rate of $75 \%$ among (15) policymakers 
Table 4. Number of Correspondences

\begin{tabular}{lccl}
\hline \multicolumn{1}{c}{ Correspondent Groups } & $n$ & Achievement (\%) & \multicolumn{1}{c}{ Designations } \\
\hline Policy makers & 20 & $75 \%$ & Top management level \\
\hline Academicians & 15 & $80 \%$ & Steering community of IBS Center \\
\hline Manufacturers & 25 & $24 \%$ & Chief Executive Officer (CEO) of the company \\
\hline Contractors & 50 & $34 \%$ & Top management level \\
\hline
\end{tabular}

replied with a feedback, $80 \%$ for (12) academicians, $24 \%$ for (6) manufacturers and $34 \%$ for (17) contractors as shown in Table 4. It can be seen that the survey received a high response rate from policymakers and academicians; whereas other group has given a low response. However all groups have fulfilled the minimum response rate required, where a response rate of $11-30 \%$ was required for manufacturing and $20-30 \%$ for contractors (Synodinos 2003; Akintoye, Fitzgerald 2000).

\section{Statistical quantitative analysis}

As further support to the study, the quantitative survey was conducted among the four targeted groups; a total of 50 responses were collected. Reliability of the criteria was investigated as well. The Cronbach's alpha $(\alpha)$ reflect the consistency of the set of items, which theoretically $\alpha$ ranges from 0 to 1 . If $\alpha$ is near 0 then the quantified answers are not reliable at all, and if it is close to 1 the answers are very reliable. As a rule of thumb, if $\alpha \geq$ 0.8 , then answers are reliable (Leontitsis, Pagge 2007). The mean value for $\alpha$-Cronbach in this study is 0.910 , which is higher than required. The result is generated using Statistical Package for Social Sciences ${ }^{\circledR}$ (SPSS) software.

\subsection{Mean ratings}

Mean rating analysis was performed by sorting and ranking the views of 50 correspondents, as presented in Table 5 . The mean value for each criterion is generated from the 50 correspondents. The top three criteria on the list are costs, transportation and optimum distance, and land sites. The costs criterion was ranked first, different from the ranking in Table 1 where transportation and optimum distance emerged at the top list of literature review. However, a different scenario was obtained for transportation and optimum distance which ranked second in both Table 1 and 5. Cost is the major concern in the global industry as the prices will change based on demand and supply needs. The establishment of an IBS manufacturing factory requires sound financial planning to ensure that the business is able to sustain and maintain production based on current and future projects, depending on market demands.

The land sites criterion ranks third in the order of importance. Identification of suitable land sites is becoming important to ensure that the IBS manufacturers are able to cope with the potential socioeconomic development expansion of the area. The decision-maker will en- sure that the land site is a strategic location that can cope with future industry expansion.

The environmental risk criterion was ranked ninth. This is due to the fact that the construction industry has to comply with the minimum requirement of the Environmental Act. The government has played an important role in ensuring that the construction industry follows the regulation and the need to have an Environmental Impact Assessment (EIA). Meanwhile, the three other criteria capacity, political and regulation, and urban criteria fall into the bottom section of Table 5. These criteria will be further discussed in the Duncan's Multiple Range Tests (DMRT).

\subsection{ANOVA}

The parametric ANOVA test is the fundamental technique used for this type of research. The test involves the ranking of variables based on their overall mean values. The analysis of variance technique simultaneously facilitates the testing of whether significant differences exist among the groups. The significance level assumed throughout the analysis is $5 \%$, following the conventional risk level that ensures a confident interval of $95 \%$.

The F-tests for ANOVA as shown in Table 5 tests the hypothesis that the selection criteria of new IBS manufacturing by the four groups do not differ from a set of specified constants. However, the results illustrated differing values of significant level for different criterions. For political and regularity criteria, a value of $p=$ 0.047 was obtained, followed by values of $p=0.040$, and $\mathrm{p}=0.008$ for personnel and urban criteria respectively. All these observed $p$ values were much smaller than the adopted significance level alpha $=0.05$, allowing the conclusion that there was significantly different view among those groups being investigated. Similar tests were carried out onto the other criterions but the result were not significant

\subsection{Duncan Multiple Range Test}

A multiple comparison procedure, the Duncan's Multiple Range Test (DMRT), was carried out with a 0.05 significance level. The purpose of the test is to determine which criteria are significantly different from one another at that particular confidence limit. Table 6 presents the results of DMRT derived from the significant difference in Table 5 (Bewick et al. 2004). The procedure is based on the comparison of the range of a subset of the sample means with the calculated least significant range. This least 
Table 5. ANOVA Results on Site Selection Criteria

\begin{tabular}{clccc}
\hline Rank & Criteria Site Selection IBS Manufacturing & Mean & F & p-value \\
\hline 2 & Transportation and Optimum Distance & 7.78 & 0.101 & 0.359 \\
\hline 1 & Costs & 7.91 & 0.871 & 0.463 \\
\hline 9 & Environmental Risk & 7.04 & 0.726 & 0.542 \\
\hline 6 & Economy Markets & 7.37 & 0.379 & 0.769 \\
\hline 5 & Infrastructure & 7.52 & 0.861 & 0.468 \\
\hline 4 & Resources and Utilization & 7.59 & 0.965 & 0.418 \\
\hline 3 & Land Sites & 7.61 & 0.645 & 0.203 \\
\hline 12 & Population & 6.39 & 1.598 & $0.047^{*}$ \\
\hline 14 & Political and Regulatory & 5.96 & 2.861 & $0.008^{*}$ \\
\hline 15 & Urban & 5.80 & 4.426 & 0.560 \\
\hline 13 & Capacity & 6.30 & 2.705 & 0.149 \\
\hline 7 & Labor & 7.24 & 1.862 & 0.628 \\
\hline 10 & Competition & 6.74 & 0.585 & $0.040^{*}$ \\
\hline 11 & Personel & 6.63 & 3.005 & 0.181 \\
\hline 8 & Inter-industry Linkage & 7.20 & 1.698 & \\
\hline
\end{tabular}

Note: $*$ Indicates the difference of p-value 0.05 among the academicians, manufacturers, contractors, and policymakers

Table 6. Duncan's Multiple Range Test

\begin{tabular}{lcccccc}
\hline \multicolumn{1}{c}{ Criteria } & Political and Regulatory & \multicolumn{3}{c}{ Urban } & \multicolumn{2}{c}{ Personal } \\
\hline Groups & 1 & 2 & 1 & 2 & 1 & 2 \\
\hline Manufacturers & 4.67 & & 3.83 & & 4.67 & 6.08 \\
\hline Academicians & 5.00 & 5.00 & 5.25 & 5.25 & 6.35 & 7.33 \\
\hline Policymakers & 6.27 & 6.27 & & 6.87 & 7.35 \\
\hline Contractors & & 6.88 & & & 68 \\
\hline
\end{tabular}

significant range increases with the number of sample means in the subset. If the range of the subset exceeds the least significant range, then the population means can be considered significantly different. It is a sequential test where the subset with the largest range is compared first, followed by smaller subsets. Once the range is found to be non-significant, then no further subsets of this group will be tested.

Using the DMRT technique, the various types of respondents (manufacturers, academicians, policymakers and contractors) can be clustered into 2 different groups - Group 1 and Group 2. The SPSS $\AA$ platform will apply the DMRT method allowing the significant differentiation between each set of group to be highlighted. The results can provide a better view and analysis among the two groups that corresponds to the required three criterions.

DMRT indicates that the political and regulatory criterion shows a higher mean for Group 2 as compared to Group 1. Correspondents from contractors provide the highest mean (6.88) while the manufacturers have the lowest mean (4.67). This signifies a significant difference in terms of view between contractors and manufacturers. It can be assumed that contractors believed that the political and regulatory criterion is very important in the early stage of the project, and that it would ensure the handover of project endorsement is obtained from the government to receive payment from the client. On the other hand, this criterion is essential to the manufacturers since their involvement was only during the early stages, particularly to acquire the license status as manufacturers from the government through the Malaysian Industry Development Authority (MIDA) and Construction Industry Development Board (CIDB).

Meanwhile, the analysed result for urban and personal criteria shows significant difference between the contractors and manufacturers. Contractors produced the highest mean for urban (6.87) and personnel (7.35) criteria while the manufacturers performed inversely, recording the lowest mean for urban (3.83) and personnel (4.67) criteria.

\section{Conclusion}

This paper presents an outlook of four groups of respondents in the assessment of criteria for IBS precast manufacturing site selection. The 15 site selection criteria are based on summarized literature findings. The statistical test further validates and ranks the criteria according to the preferences of the respondents. There is a significant difference in the results of the one-way ANOVA; the cri- 
teria involved were political and regulatory, urban and personnel. In contrast, the political and regulatory criteria had the least significant value among the group's preference with a p-value of 0.047 . Therefore, a further analysis using DMRT was conducted to highlight the different level of preferences between group 1 and 2 as well as among the four groups. The results illustrated that the highest significant difference among the four groups was between the contractors and the manufacturers.

This study has improved Singh (1976) finding by extending the 11 criteria to 15 site selection criteria for IBS precast manufacturing. The additional criteria which are vital for the studies were; environment risk, population, competition and capacity. Based on the Environment Act 1974, the environment risk criterion is becoming more important. This is shown with the amendment of the law on the Environmental Quality Act 2001 by the government and the continuous amendments by CIDB with the compilation of the report on environmental acts, laws and regulations related to construction industry (EQA 2001; CIDB 2008).

While the population criteria had dropped in ranking from 7 to 12; due to the less impact to site selection and proper allocation of factory distance from the housing area; contrastingly the competition criteria ranking had increase into the $10^{\text {th }}$ position as the existence of IBS precast manufacturing is vital in order to capture good market demand. However the criteria of capacity remain in the same ranking position; where in the case of capacity becoming less popular with the development of new technologies, the production of the factories could be increase with proper management and marketing to fulfil the demand.

The results of this study provide an indication that the construction industry must move to a new paradigm in prioritizing its criteria for selecting new IBS precast manufacturing sites. The approach implemented in this study has contributed to the methodology for further research in criteria listing, intuitive ranking of preferences.

\section{Acknowledgement}

The authors wish to thank the Construction Industry Development Board (CIDB) Malaysia for providing the data and Universiti Sains Malaysia (USM) for funding this research under FRGS (203/PAWAM/6071219) as well as Universiti Pendidikan Sultan Idris (UPSI) for supporting this research.

\section{References}

Adetunji, I.; Price, A.; Fleming, P.; Kemp, P. 2003. Sustainability and the UK construction industry - a review, in Proceeding of the Institution of Civil Engineers - Engineering Sustainability 156(4): 185-199. http://dx.doi.org/10.1680/ensu.2003.156.4.185

Akintoye, A.; Fitzgerald, E. 2000. A survey of current cost estimating practices in the UK, Construction Management and Economics 18(2): 161-172.

http://dx.doi.org/10.1080/014461900370799
Aras, H.; Erdogmus, S.; Koc, E. 2004. Multi-criteria selection for a wind observation station location using analytic hierarchy process, Renewable Energy 29(8): 1383-1392. http://dx.doi.org/10.1016/j.renene.2003.12.020

Azman, M. N. A.; Ahamad, M. S. S.; Majid, T. A.; Hanafi, M. H. 2010a. The common approach in off-site construction industry, Australian Journal of Basic and Applied Sciences 4(9): 4478-4482.

Azman, M. N. A.; Ahamad, M. S. S.; Majid, T. A.; Hanafi, M. H. 2010b. Perspective of Malaysian industrialised building system on the modern method of construction, in Proc. of the $11^{\text {th }}$ Asia Pacific Industrial Engineering and Management Systems Conference, Malacca, Malaysia.

Azman, M. N. A.; Ahamad, M. S. S.; Majid, T. A.; Hanafi, M. H. 2011. Permanent and mobile industrialised building system manufacturing plant based on Malaysian case study, in Proc. of World Conference on Information Technology, Antalya, Turkey.

Balnaves, M.; Caputi, P. 2001. Introduction quantitative research methods. London: SAGE Publications.

Bewick, V.; Cheek, L.; Ball, J. 2004. Statistics review 9: oneway analysis of variance, Critical Care 8(2): 130-136. http://dx.doi.org/10.1186/cc2836

Blismas, N.; Wakefield, R. 2009. Concrete prefabricated housing via advances in systems technologies. Development of a technology roadmap, Engineering Construction and Architectural Management 17(1): 99-110. http://dx.doi.org/10.1108/09699981011011357

Chang, N.-B.; Parvathinathan, G.; Breeden, J. B. 2008. Combining GIS with fuzzy multicriteria decision-making for landfill siting in a fast-growing urban region, Journal of Environmental Management 87(1): 139-153. http://dx.doi.org/10.1016/j.jenvman.2007.01.011

Chen, Y.; Okudan, G. E.; Riley, D. R. 2010. Sustainable performance criteria for construction method selection in concrete buildings, Automation in Construction 19(2): 235-244. http://dx.doi.org/10.1016/j.autcon.2009.10.004

Chou, S.-Y.; Chang, Y.-H. 2008. A decision support system for supplier selection based on a strategy-aligned fuzzy SMART approach, Expert Systems with Applications 34(4): 2241-2253. http://dx.doi.org/10.1016/j.eswa.2007.03.001

Chou, T.-Y.; Hsu, C.-L.; Chen, M.-C. 2008. A fuzzy multi-criteria decision model for international tourist hotels location selection, International Journal of Hospitality Management 27(2): 293-301. http://dx.doi.org/10.1016/j.ijhm.2007.07.029

CIDB 2003. Industrialized Building System (IBS) roadmap 2003-2010, Kuala Lumpur, Construction Industry Development Board (CIDB).

CIDB 2008. Compilation of environmental acts laws and regulations related to construction industry. Kuala Lumpur: Construction Industry Development Board (CIDB).

CIDB 2010. IBS info. IBS Centre, Construction Industry Development Board (CIDB).

Dulaimi, M. F.; Ling, F. Y. Y.; Ofori, G. 2004. Engines for change in Singapore's construction industry: an industry view of Singapore's construction 21 report, Building and Environment 39(6): 699-711. http://dx.doi.org/10.1016/j.buildenv.2004.01.011

Ekmekçioğlu, M.; Kaya, T.; Kahraman, C. 2010. Fuzzy multicriteria disposal method and site selection for municipal solid waste, Waste Management 30(8-9): 1729-1736. http://dx.doi.org/10.1016/j.wasman.2010.02.031

EQA 2001. Environment quality (amendment) act 2001, Kuala Lumpur: Lawnet Pencetakan Nasional Malaysia Berhad. 
Farahani, R. Z.; Steadieseifi, M.; Asgari, N. 2010. Multiple criteria facility location problems: a survey, Applied Mathematical Modelling 34(7): 1689-1709. http://dx.doi.org/10.1016/j.apm.2009.10.005

Fernández, I.; Ruiz, M. C. 2009. Descriptive model and evaluation system to locate sustainable industrial areas, Journal of Cleaner Production 17(1): 87-100. http://dx.doi.org/10.1016/j.jclepro.2008.02.011

Flynn, B. B.; Sakakibara, S.; Schroeder, R. G.; Bates, K. A.; Flynn, E. J. 1990. Empirical research methods in operations management, Journal of Operations Management 9(2): 250-284. http://dx.doi.org/10.1016/0272-6963(90)90098-X

Kahraman, C.; Ruan, D.; Dogan, I. 2003. Fuzzy group decision-making for facility location selection, Information Sciences 157(0): 135-153. http://dx.doi.org/10.1016/S0020-0255(03)00183-X

Kamar, K. A. M.; Hamid, Z. A.; Azman, M. N. A.; Ahamad, M. S. S. 2011. Industrialized Building System (IBS): revisiting issues of definition and classification, International Journal of Emerging Sciences 1(2): 120.

Keeney, R. L.; Raiffa, H. 1976. Decisions with multiple objectives: preferences and value tradeoffs. New York: Wiley.

Lahdelma, R.; Salminen, P.; Hokkanen, J. 2002. Locating a waste treatment facility by using stochastic multicriteria acceptability analysis with ordinal criteria, European Journal of Operational Research 142(2): 345-356. http://dx.doi.org/10.1016/S0377-2217(01)00303-4

Leontitsis, A.; Pagge, J. 2007. A simulation approach on Cronbach's alpha statistical significance, Mathematics and Computers in Simulation 73(5): 336-340. http://dx.doi.org/10.1016/j.matcom.2006.08.001

Lin, C.-T.; Juan, P.-J. 2009. Developing a hierarchy relation with an expert decision analysis process for selecting the optimal resort type for a Taiwanese international resort park, Expert Systems with Applications 36(2): 1706-1719. http://dx.doi.org/10.1016/j.eswa.2007.11.044

Lovell, H.; Smith, S. J. 2010. Agencement in housing markets: the case of the UK construction industry, Geoforum 41(3): 457-468. http://dx.doi.org/10.1016/j.geoforum.2009.11.015

Majid, T. A.; Azman, M. N. A.; Zakaria, S. A. S.; Yahya, A. S.; Zaini, S. S.; Ahamad, M. S. S.; Hanafi, M. H. 2011. Quantitative analysis on the level of IBS acceptance in the Malaysian construction industry, Journal of Engineering Science and Technology 6(2): 179-190.

MITI 2010. Malaysia - Towards Global Competitiveness. Malaysia: MITI Weekly Bulletin.

Norese, M. F. 2006. ELECTRE III as a support for participatory decision-making on the localisation of waste-treatment plants, Land Use Policy 23(1): 76-85. http://dx.doi.org/10.1016/j.landusepol.2004.08.009

Rachdawong, R.; Apawootichai, S. 2003. Development of criterion weights for preliminary site selection: a pilot project of Supanburi industrial estate, Songklanakarin Journal of Science \& Technology 25(6): 773-781.
Sener, S.; Sener, E.; Nas, B.; Karagüzel, R. 2010. Combining AHP with GIS for landfill site selection: a case study in the Lake Beysehir catchment area (Konya, Turkey), Waste Management 30(11): 2037-2046. http://dx.doi.org/10.1016/j.wasman.2010.05.024

Shen, C.-Y.; Yu, K.-T. 2009. A generalized fuzzy approach for strategic problems: the empirical study on facility location selection of authors' management consultation client as an example, Expert Systems with Applications 36(3): 4709-4716. http://dx.doi.org/10.1016/j.eswa.2008.06.035

Singh, M. S. 1976. Spatial and structural pattern of manufacturing industry in west Malaysia from 1957-1975: a case study in industrial: PhD thesis, University of London, London.

Sinuany-Stern, Z.; Mehrez, A.; Tal, A.-G.; Shemuel, B. 1995. The location of a hospital in a rural region: the case of the Negev, Location Science 3(4): 255-266. http://dx.doi.org/10.1016/0966-8349(96)00002-2

Synodinos, N. E. 2003. The "art" of questionnaire construction: some important consideration for manufacturing studies, Integrated Manufacturing Systems 14(3): 221-237. http://dx.doi.org/10.1108/09576060310463172

Tabari, M.; Kaboli, A.; Aryanezhad, M. B.; Shahanaghi, K.; Siadat, A. 2008. A new method for location selection: a hybrid analysis, Applied Mathematics and Computation 206(2): 598-606. http://dx.doi.org/10.1016/j.amc.2008.05.111

Tam, V. W. Y. 2007. On prefabrication implementation for different project types and procurement methods in Hong Kong, Journal of Engineering, Design and Technology 5(1): 6880. http://dx.doi.org/10.1108/17260530710746614

Treasury 2008:2008. Application Industrialized Building System (IBS) in government project. Ministry of Finance, Malaysia.

Tuan Seik, F. 2001. Planning and design of Tampines, an award-winning high-rise, high-density township in Singapore, Cities 18(1): 33-42. http://dx.doi.org/10.1016/S0264-2751(00)00052-4

Tuzkaya, G.; Önüt, S.; Tuzkaya, U. R.; Gülsün, B. 2008. An analytic network process approach for locating undesirable facilities: an example from Istanbul, Turkey, Journal of Environmental Management 88(4): 970-983. http://dx.doi.org/10.1016/j.jenvman.2007.05.004

Tzeng, G.-H.; Teng, M.-H.; Chen, J.-J.; Opricovic, S. 2002. Multicriteria selection for a restaurant location in Taipei, International Journal of Hospitality Management 21(2): $171-187$ http://dx.doi.org/10.1016/S0278-4319(02)00005-1

Vahidnia, M. H.; Alesheikh, A. A.; Alimohammadi, A. 2009. Hospital site selection using fuzzy AHP and its derivatives, Journal of Environmental Management 90(10): 30483056. http://dx.doi.org/10.1016/j.jenvman.2009.04.010

Weber, A. 1909. Uber den Standort der Industrien, Tübingen. Theory of the Location Industries, Chicago, University of Chicago Press. 
Mohamed Nor Azhari AZMAN. Senior Lecturer, PhD at the Faculty of Technical and Vocational, Sultan Idris University of Education. He is the author, co-author and editor of several books or book chapters on Industrialized Building System (IBS) as well as published more than 40 scientific papers. Research interests focus on the study of Industrialised Building System (IBS), Precast Manufacturing Plant and Spatial Site Selection.

Mohd Sanusi S. AHAMAD. Associate Professor, PhD at the School of Civil Engineering. Engineering Campus, Universiti Sains Malaysia. He is the author and co-author of more than 120 technical and scientific papers. Research interests include Geo-Spatial Decisions, Spatial Site Selections, and Geo-Measurement Sciences.

Taksiah A. MAJID. Associate Professor, PhD at the School of Civil Engineering, Universiti Sains Malaysia, author and co-author and editor of several Industrialized Building System (IBS) books, Expert Panel for IBS with Construction Research Institute of Malaysia and published more than 80 scientific papers. Research interests include Industrialized Building System (IBS), Seismic and Wind Engineering and Computational Mechanics.

Ahmad Shukri YAHAYA. Associate Professor at the School of Civil Engineering, Engineering Campus, Universiti Sains Malaysia. $\mathrm{He}$ is the author and co-author of more than 100 scientific papers. Research interests include Environmental Modeling, Engineering Statistics and Data Analyses

Mohd Hanizun HANAFI. Senior Lecturer, $\mathrm{PhD}$ at the Department of Construction Management, School of Housing, Building and Planning, Universiti Sains Malaysia. Author and co-author of more than 20 scientific papers. Research interests include Construction Management, Quantity Surveying, Industrialized Building System, Labour Productivity and Simulation in Construction. 